http://jmscr.igmpublication.org/home/

ISSN (e)-2347-176x ISSN (p) 2455-0450

crossref DOI: https://dx.doi.org/10.18535/jmscr/v7i7.45

\title{
Effect of Acupuncture-Moxibustion on Adhesive Scapulohumeral Periarthritis: A Case Study
}

\author{
Authors \\ Pradeep Antony* ${ }^{1}$ BEMS, PG Dip. in Acu., MSc, Deepthi A. K ${ }^{2}$ BEMS, PG Dip. in Acu., \\ Tinu Varghese ${ }^{3}$, ME, PhD \\ ${ }^{1}$ Head, "The Chinese Needle"- Acupuncture Clinic, Trivandrum, Kerala, India \\ ${ }^{2}$ Consultant, "The Chinese Needle"- Acupuncture Clinic, Trivandrum, Kerala, India \\ ${ }^{3}$ Research Associate, "The Chinese Needle"- Acupuncture Clinic, Trivandrum, Kerala, India \\ *Corresponding Author \\ Pradeep Antony
}

The Chinese Needle"- Acupuncture Clinic, Trivandrum, Kerala, India

\begin{abstract}
Objective: To determine the efficacy of acupuncture-moxibustion in patients with adhesive scapulahumeral periarthritis

Materials and Methods: A combination of Electro-acupuncture, moxibustion and stretching movements was followed to treat diagnosed cases of adhesive scapulohumeral periarthritis.

Result: Pain reduction, improved range of motion of shoulder and better quality of life and sleep are marked in this study.

Conclusion: This study concluded that various therapeutic techniques like acupuncture, electric stimulation, moxibustion and some stretching movements have a significant effect in pain reduction, improvement in range of motion and quality of sleep.

Keywords: Adhesive Scapulohumeral Periarthritis (ASP), Gleno-Humeral Joint (GH join), Non-Steroidal Anti-Inflammatory Drugs (NSAID), Numerical Rating Scale (NRS), Normal Range of Motion (ROM).
\end{abstract}

\section{Introduction}

Adhesive scapulohumeral periarthritis (ASP) is also known as adhesive capsulitis or commonly known as frozen shoulder. It is a condition of unknown cause with inflammation and stiffness of shoulder capsule and the connective tissue surrounding the GH joint(gleno-humeraljoint) and it is characterized by pain and limitation of movement of the shoulder joint. Pain usually get worsen at night and with cold weather. It is one of the most difficult and painful joint disorders that affect $2-5 \%$ of the people of the society in the age range of $40-60^{(1)}$. Children are affected very rarely, females are less affected than male and there is no genetic intention or race about this disorder. This condition is prevalent among both type-1 and type-2 diabetes patients and also among pre-diabetes patients ${ }^{(2)}$. Cortisone injections, non-steroidal anti-inflammatory drugs (NSAID) and physiotherapy are the available 
conventional treatments for $\mathrm{ASP}^{(3)}$. But in the long run, unfortunately, none of these treatments has proven to be clearly effective for $\mathrm{ASP}^{(4)}$. Also, varying degrees of side effects are shown with these interventions.

ASP can be treated with acupuncture simply and effectively. The effect of acupuncture on shoulder pain, stiffness and associated symptoms is studied by some randomized control trials by using different acupuncture-point combinations and different methods \& techniques. The German Randomized Acupuncture Trial for chronic pain of shoulder, after 15 sessions of treatment showed much improvement in shoulder mobility immediately after treatment and after 3 months ${ }^{(5)}$. In a randomized control trial, it is found that motion style acupuncture treatment is more effective than conventional acupuncture treatment $^{(6)}$. A comparative study of exercise group with acupuncture plus exercise group showed that exercise plus acupuncture group experienced significantly greater improvement with treatment ${ }^{(7)}$. A Systematic review and metaanalysis of randomized controlled trials found encouraging evidence for the effectiveness of acupuncture at Tiaokou (ST 38) for shoulder adhesive capsulitis ${ }^{(8)}$. A randomized controlled double-blinded study on immediate pain relief in adhesive capsulitis by Integrating acupuncture with conservative therapy showed superior effectiveness with respect to the time course of the recovery process in ASP compared with conservative therapy alone ${ }^{(9)}$.

ASP can be classified as primary or secondary. If the onset is idiopathic, it is considered as primary and if it is due to any known cause, injury or surgery, it is considered as secondary. Traditional Chinese medicine categorizes ASP under $\mathrm{Bi}$ Syndrome caused by invasion of either wind or cold or damp or heat, or due to the deficiency of either yin or yang or qi and blood ${ }^{(10)}$.

\section{Materials and Methods}

Ten numbers of diagnosed cases of ASP (7 Males, 3 Females) are selected randomly for treatment.
The inclusion criteria were (1) primary ASP; (2) age $30-65$ years; (3) one sided ASP for at least 2 months; (4) duration of the ASP not more than 2 years. The exclusion criteria were (1) secondary ASP (2) any other treatment involving analgesics or NSAID; (3) under any treatment related with neurological or psychiatric or de-addiction.

All patients received 15 sessions of treatments every other day and three sessions in each week, each session lasts for 35-45 minutes. The treatment procedure has 3 phases.

Phase -1 : Needling is done in sitting posture first at ipsilateral Tiaokou (ST 38) and elicited strong "DEQI" (needling sensation). Then asked the patients to move his/her arm in all possible ways like flexion, extension, abduction, adduction, medial rotation, lateral rotation etc. for five minutes.

Phase - 2: Other acupoints [Jianyu (SI 15), Jianliao (SJ 14), Tianzong (SI 11), Naoshu (SI 10), Hegu (LI 4), Waiguan (SJ 5), Feiyang (BL 57) and "Ashi" (Tender points, 1-3 numbers) points] are needled ipsilateral and elicited strong "DEQI" (needling sensation). 1 - 3 pairs of most tender/stiff points were selected, connected with an electric stimulator and DD stimulation (combined dense and dispersed wave) was given for 20minutes. Warming needle moxibustion was given according to traditional differentiation of syndromes. After 20 minutes, Electro-stimulation stopped and the needles removed except Tiaokou (ST 38) and Feiyang (BL 58).

Phase -3 : The remaining two acupoints (Tiaokou - ST 38, Feiyang-BL 58) are retained for 5-10 minutes more with electric-stimulation (dense wave $-50-100 /$ second) and asked the patients to move the arm in all directions with the maximum possible stretch (active and passive).

This total procedure (all 3 phases) is considered as one session of treatment.

\section{Result}

Tables $1-10$ are the results of each case tabulated separately. The status of pain and mobility of the shoulder are noted 4 times - initially (before 


\section{JMSCR Vol||07||Issue||07||Page 228-233||July}

starting the treatment), after 5 sessions of treatment, after 10 sessions and finally after 15 sessions. Each time, the assessment was done in both active and passive phases. The scales used were Numerical Rating Scale (NRS for pain) and Range of Motion (ROM) of shoulder in degrees.

\section{Scale - 1 NRS for pain}

NRS score 0 is considered as 'no pain'; scores $1,2 \& 3$ are considered as 'mild pain'; 4,5 \& 6 are considered as 'moderate pain'; 7,8 \& 9 are 'severe pain' and 10 as 'worst possible pain'.

\begin{tabular}{|l|l|l|l|l|l|l|l|l|l|l|}
\hline 0 & 1 & 2 & 3 & 4 & 5 & 6 & 7 & 8 & 9 & 10 \\
\hline $\begin{array}{l}\text { No } \\
\text { Pain }\end{array}$ & Mild Pain & & \multicolumn{9}{l}{ Moderate Pain } & Severe Pain & & $\begin{array}{l}\text { Worst } \\
\text { Possible } \\
\text { Pain }\end{array}$ \\
\hline
\end{tabular}

\section{Scale - 2 Normal Range of Motion (ROM) of Shoulder in degrees}

Normal range of abduction is $180^{\circ}$, normal range of flexion is $180^{\circ}$ and normal range of External Rotation is $90^{\circ}$

Table 1: Case 1, 62 yrs, Male

\begin{tabular}{|l|c|c|c|c|c|}
\hline & NRS for Pain & ROM & Abduction & Flexion & External Rotation \\
\hline \multirow{2}{*}{ Initial } & \multirow{2}{*}{8} & Active & 80 & 100 & 40 \\
\cline { 3 - 6 } & & Passive & 90 & 120 & 45 \\
\hline \multirow{2}{*}{$\begin{array}{l}\text { After } \\
\text { Sessions }\end{array}$} & \multirow{2}{*}{5} & Active & 90 & 120 & 50 \\
\hline \multirow{2}{*}{$\begin{array}{l}\text { After } \\
\text { Sessions }\end{array}$} & \multirow{2}{*}{10} & Passive & 100 & 140 & 50 \\
\hline $\begin{array}{l}\text { After } \\
\text { Sessions }\end{array}$ & \multirow{2}{*}{2} & Active & 100 & 130 & 55 \\
\cline { 3 - 6 } & & Passive & 110 & 150 & 55 \\
\cline { 3 - 6 } & & Active & 110 & 140 & 55 \\
\hline
\end{tabular}

Table 2: Case 2, 41 yrs, Male

\begin{tabular}{|c|c|c|c|c|c|c|}
\hline & & NRS for Pain & ROM & Abduction & Flexion & External Rotation \\
\hline \multirow{2}{*}{\multicolumn{2}{|c|}{ Initial }} & \multirow{2}{*}{5} & Active & 100 & 120 & 30 \\
\hline & & & Passive & 110 & 125 & 35 \\
\hline \multirow{2}{*}{$\begin{array}{l}\text { After } \\
\text { Sessions }\end{array}$} & \multirow[t]{2}{*}{5} & \multirow{2}{*}{3} & Active & 110 & 140 & 40 \\
\hline & & & Passive & 115 & 150 & 45 \\
\hline \multirow{2}{*}{$\begin{array}{l}\text { After } \\
\text { Sessions }\end{array}$} & \multirow[t]{2}{*}{10} & \multirow{2}{*}{3} & Active & 115 & 150 & 50 \\
\hline & & & Passive & 120 & 160 & 55 \\
\hline \multirow{2}{*}{$\begin{array}{l}\text { After } \\
\text { Sessions }\end{array}$} & & \multirow{2}{*}{3} & Active & 120 & 155 & 55 \\
\hline & & & Passive & 125 & 160 & 60 \\
\hline
\end{tabular}

Table 3: Case 3, 32 yrs, Male

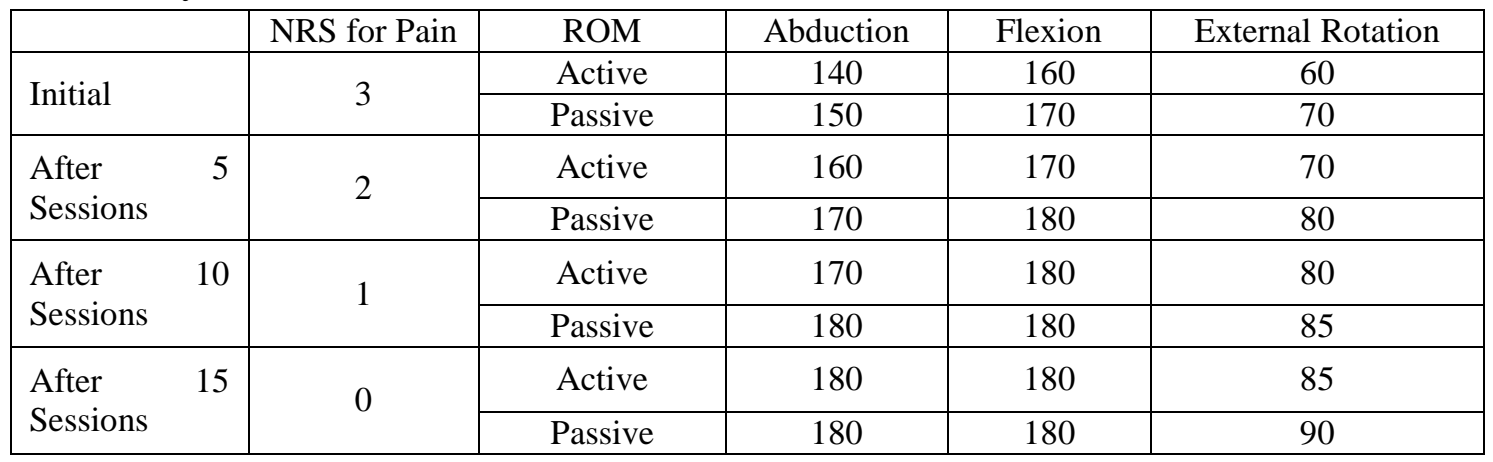


Table 4: Case 4, 52 yrs, Male

\begin{tabular}{|c|c|c|c|c|c|}
\hline & NRS for Pain & ROM & Abduction & Flexion & External Rotation \\
\hline \multirow[b]{2}{*}{ Initial } & \multirow{2}{*}{6} & Active & 90 & 110 & 45 \\
\hline & & Passive & 100 & 120 & 55 \\
\hline \multirow{2}{*}{$\begin{array}{l}\text { After } \\
\text { Sessions }\end{array}$} & \multirow{2}{*}{5} & Active & 110 & 130 & 55 \\
\hline & & Passive & 120 & 140 & 65 \\
\hline \multirow{2}{*}{$\begin{array}{l}\text { After } \\
\text { Sessions } \\
\end{array}$} & \multirow{2}{*}{4} & Active & 125 & 150 & 65 \\
\hline & & Passive & 130 & 160 & 75 \\
\hline \multirow{2}{*}{$\begin{array}{l}\text { After } \\
\text { Sessions }\end{array}$} & \multirow{2}{*}{3} & Active & 135 & 165 & 70 \\
\hline & & Passive & 140 & 170 & 75 \\
\hline
\end{tabular}

Table 5: Case 5, 49 yrs, Male

\begin{tabular}{|c|c|c|c|c|c|c|}
\hline & & NRS for Pain & ROM & Abduction & Flexion & External Rotation \\
\hline \multirow{2}{*}{\multicolumn{2}{|c|}{ Initial }} & \multirow{2}{*}{4} & Active & 120 & 150 & 60 \\
\hline & & & Passive & 125 & 160 & 70 \\
\hline \multirow{2}{*}{$\begin{array}{l}\text { After } \\
\text { Sessions }\end{array}$} & \multirow[t]{2}{*}{5} & \multirow{2}{*}{3} & Active & 125 & 155 & 70 \\
\hline & & & Passive & 130 & 165 & 75 \\
\hline \multirow{2}{*}{$\begin{array}{l}\text { After } \\
\text { Sessions }\end{array}$} & \multirow[t]{2}{*}{10} & \multirow{2}{*}{3} & Active & 130 & 160 & 75 \\
\hline & & & Passive & 135 & 170 & 80 \\
\hline \multirow{2}{*}{$\begin{array}{l}\text { After } \\
\text { Sessions }\end{array}$} & 15 & \multirow{2}{*}{3} & Active & 130 & 160 & 80 \\
\hline & & & Passive & 135 & 170 & 85 \\
\hline
\end{tabular}

Table 6: Case 6, 39 yrs, Female

\begin{tabular}{|c|c|c|c|c|c|}
\hline & NRS for Pain & ROM & Abduction & Flexion & External Rotation \\
\hline \multirow{2}{*}{ Initial } & \multirow{2}{*}{5} & Active & 130 & 150 & 60 \\
\hline & & Passive & 145 & 170 & 65 \\
\hline \multirow{2}{*}{$\begin{array}{l}\text { After } \\
\text { Sessions }\end{array}$} & \multirow{2}{*}{3} & Active & 150 & 160 & 70 \\
\hline & & Passive & 165 & 175 & 75 \\
\hline \multirow{2}{*}{$\begin{array}{l}\text { After } \\
\text { Sessions }\end{array}$} & \multirow{2}{*}{2} & Active & 160 & 170 & 75 \\
\hline & & Passive & 175 & 180 & 80 \\
\hline \multirow{2}{*}{$\begin{array}{ll}\text { After } & 15 \\
\text { Sessions } & \end{array}$} & \multirow{2}{*}{1} & Active & 170 & 180 & 80 \\
\hline & & Passive & 180 & 180 & 85 \\
\hline
\end{tabular}

Table 7: Case 7, 58 yrs, Female

\begin{tabular}{|c|c|c|c|c|c|}
\hline & NRS for Pain & ROM & Abduction & Flexion & External Rotation \\
\hline \multirow{2}{*}{ Initial } & \multirow{2}{*}{9} & Active & 60 & 80 & 30 \\
\hline & & Passive & 65 & 90 & 30 \\
\hline \multirow{2}{*}{$\begin{array}{l}\text { After } \\
\text { Sessions }\end{array}$} & \multirow{2}{*}{7} & Active & 75 & 100 & 35 \\
\hline & & Passive & 80 & 110 & 35 \\
\hline \multirow{2}{*}{$\begin{array}{l}\text { After } \\
\text { Sessions }\end{array}$} & \multirow{2}{*}{6} & Active & 85 & 110 & 40 \\
\hline & & Passive & 90 & 120 & 40 \\
\hline \multirow{2}{*}{$\begin{array}{ll}\text { After } & 15 \\
\text { Sessions } & \\
\end{array}$} & \multirow[b]{2}{*}{5} & Active & 90 & 120 & 40 \\
\hline & & Passive & 95 & 125 & 45 \\
\hline
\end{tabular}

Table 8: Case 8, 42 yrs, Male

\begin{tabular}{|c|c|c|c|c|c|}
\hline & NRS for Pain & ROM & Abduction & Flexion & External Rotation \\
\hline \multirow{2}{*}{ Initial } & \multirow{2}{*}{3} & Active & 100 & 135 & 55 \\
\hline & & Passive & 110 & 145 & 60 \\
\hline \multirow{2}{*}{$\begin{array}{l}\text { After } \\
\text { Sessions }\end{array}$} & \multirow{2}{*}{2} & Active & 120 & 150 & 65 \\
\hline & & Passive & 130 & 160 & 70 \\
\hline \multirow{2}{*}{$\begin{array}{l}\text { After } \\
\text { Sessions }\end{array}$} & \multirow{2}{*}{2} & Active & 130 & 160 & 75 \\
\hline & & Passive & 140 & 170 & 80 \\
\hline \multirow{2}{*}{$\begin{array}{ll}\text { After } & 15 \\
\text { Sessions } & \end{array}$} & \multirow{2}{*}{1} & Active & 140 & 170 & 80 \\
\hline & & Passive & 150 & 175 & 85 \\
\hline
\end{tabular}


Table 9: Case 9, 63 yrs, Male

\begin{tabular}{|l|c|c|c|c|c|}
\hline & NRS for Pain & ROM & Abduction & Flexion & External Rotation \\
\hline \multirow{2}{*}{ Initial } & \multirow{2}{*}{8} & Active & 80 & 100 & 40 \\
\cline { 4 - 7 } & & Passive & 85 & 110 & 45 \\
\hline $\begin{array}{l}\text { After } \\
\text { Sessions }\end{array}$ & \multirow{2}{*}{8} & Active & 90 & 110 & 45 \\
\cline { 4 - 6 } $\begin{array}{l}\text { After } \\
\text { Sessions }\end{array}$ & \multirow{2}{*}{70} & Passive & 95 & 120 & 50 \\
\hline $\begin{array}{l}\text { After } \\
\text { Sessions }\end{array}$ & \multirow{2}{*}{7} & Active & 95 & 120 & 50 \\
\cline { 3 - 6 } & \multirow{2}{*}{7} & Passive & 100 & 125 & 50 \\
\cline { 3 - 6 } & & Active & 100 & 125 & 50 \\
\cline { 3 - 6 } & & Passive & 105 & 130 & 55 \\
\hline
\end{tabular}

Table 10: Case 10, 62 yrs, Female

\begin{tabular}{|l|c|c|c|c|c|}
\hline & NRS for Pain & ROM & Abduction & Flexion & External Rotation \\
\hline \multirow{2}{*}{ Initial } & \multirow{2}{*}{7} & Active & 90 & 120 & 45 \\
\cline { 3 - 6 } & & Passive & 95 & 130 & 50 \\
\hline \multirow{2}{*}{$\begin{array}{l}\text { After } \\
\text { Sessions }\end{array}$} & \multirow{2}{*}{6} & Active & 100 & 135 & 50 \\
\cline { 4 - 7 } $\begin{array}{l}\text { After } \\
\text { Sessions }\end{array}$ & \multirow{2}{*}{5} & Passive & 105 & 145 & 55 \\
\hline $\begin{array}{l}\text { After } \\
\text { Sessions }\end{array}$ & \multirow{2}{*}{5} & Active & 110 & 150 & 55 \\
\cline { 3 - 6 } & \multirow{2}{*}{5} & Passive & 115 & 160 & 60 \\
\cline { 3 - 6 } & & Active & 120 & 160 & 60 \\
\cline { 3 - 6 } & & Passive & 125 & 165 & 65 \\
\hline
\end{tabular}

\section{Discussion}

Ten diagnosed cases of primary ASP ( 7 males, 3 females) were selected randomly with complaints of pain and limitation of movements of unilateral shoulder joint. The age of the patients ranges from $32-63$ and the complaints last for 3-20 months. 5 of them were diabetic and no one has the history of traumatic injury of shoulder or any known cause for ASP.

This method of acupuncture is aimed to reduce pain, to improve mobility and to prevent disabilities. This 'tri-phased' method with the combination of acupuncture, electric stimulation, moxibustion and shoulder stretch during the treatment is found very effective for improving all symptoms of ASP in short period.

Case -3 presented with complaints of ASP for 3 months, non-diabetic, aged 32 and the symptoms were mild before treatment has fully recovered after 15 sessions. Case -6 presented with complaints of ASP for 5 months, non-diabetic, aged 39 and the symptoms were moderate before treatment has recovered almost 95\% after 15 sessions. Whereas, case -7 , case -9 and case 10 are diabetic, presented with complaints of ASP for $12-20$ months, symptoms were severe before treatment have got only satisfactory results after 15 sessions of treatment and need more sessions. ASP is a disabling condition which usually needs a long term treatment. Different methods of treatment are available for its management. Acupuncture, in general, improves the pain and mobility of shoulder in all direction like adduction, abduction, flexion, extension and medial \& lateral rotation. Also it improves the quality of life and quality of sleep.

\section{Conclusion}

Little can be concluded from this review because a small number of clinical trials have been done. The combination of acupuncture, electric stimulation, moxibustion and maximum possible stretching during treatment marked a significant difference in symptoms of ASP. So it could be offered to patients with ASP as a method to improve the pain and mobility. Further well designed clinical trials are needed for the better evaluation. 


\section{Acknowledgements}

The authors like to express their thanks to the patients attending the acupuncture clinic, "The Chinese Needle"- Acupuncture Clinic, Trivandrum, Kerala, India, for their support and encouragement during this work.

\section{Disclosure}

Conflict of interest: None.

\section{References}

1. Buchbindar R, Hoving L J, Green $S$ et al,.Short course prednisolone for adhesive capsulitis (frozen shoulder or stiff painful shoulder) : a randomized, double blinded, placebo controlled trial. Ann Rheum Dis 2004; 1460-1469.

2. Ogilvie-Harris D, D'Angelo G. Arthroscopic surgery of the shoulder. Sports Medicine. 1990;9(2): 1208.

3. R.J. Meislin, J.W. Sperling, T.P. Stitik. Persistent shoulder pain: epidemiol-ogy, pathophysiology, and diagnosis. Am J Orthop (Belle Mead NJ), 34 (12 suppl 1) (2005), pp. 5-9.

4. J.J. Luime, B.W. Koes, I.J. Hendriksen, et al.Prevalence and incidence of shoulder pain in the general population; a systematic review. Scand J Rheumatol, 33 (2) (2004), pp. 73-81.

5. Albrecht Molsberger, ThomasSchneider, HermannGotthardt, Attyla Drabik. German Randomized Acupuncture Trial for chronic shoulder pain (GRASP) - A pragmatic, controlled, patient-blinded, multi-centre trial in an outpatient care environment. Pain. 151(1)2010;146-154.

6. Guang-Xia Shi, Bao-Zhen Liu, Jun Wang, Qing-Nan Fu, San-Feng Sun, RuiLi Liang,Jing Li, Jian-Feng Tu, Cheng Tan, and Cun-Zhi Liu.Motion style acupuncture therapy for shoulder pain: a randomized controlled trial. J Pain Res. 2018; 11: 2039-2050.
7. Sun KO, Chan KC, Lo SL, Fong DY. Acupuncture for frozen shoulder. Hong Kong Med J. 2001; 7(4):381-91.

8. Chao Yang, TaoTao Lv, TianYuan Yu, Ste ven Wong, MengQian Lu, and YiZhen Li. Acupuncture at Tiaokou (ST38) for Shoulder Adhesive Capsulitis: What Strengths Does It Have? A Systematic Review and Meta-Analysis of Randomized Controlled Trials. Evidence-Based Complementary and Alternative Medicine.2018; Aricle ID 4197659, 11 pages.

9. Schröder S, Meyer-Hamme G, Friedemann T, Kirch S, Hauck M, Plaetke R, Friedrichs S, Gulati A, Briem D. Immediate Pain Relief in Adhesive Capsulitis by Acupuncture-A Randomized Controlled Double-Blinded Study.Pain Med. 2017; 2235-2247.

10. XinghuaBai. Acupuncture in Clinical Practice: A Practical Guide to the Use of Acupuncture and Related Therapies. Butterworth-Heinemann, 1996 - Medical 286 pages. 